\title{
A lean approach to service productivity improvements: Synergy or oxymoron?
}

\author{
Per Carlborg, Daniel Kindström and Christian Kowalkowski
}

\section{Linköping University Post Print}

\section{Tweet}

N.B.: When citing this work, cite the original article.

Original Publication:

Per Carlborg, Daniel Kindström and Christian Kowalkowski, A lean approach to service productivity improvements: Synergy or oxymoron?, 2013, Managing Service Quality, (23), 4, 291-304.

http://dx.doi.org/10.1108/MSQ-04-2013-0052

Copyright: Emerald

http://www.emeraldinsight.com/

Postprint available at: Linköping University Electronic Press

http://urn.kb.se/resolve?urn=urn:nbn:se:liu:diva-95804 


\section{A lean approach to service productivity improvements: Synergy or oxymoron?}

Purpose: Service productivity continues to receive ever-greater amounts of attention as service covers a greater portion of the economy. As competition increases, service productivity becomes increasingly important. This study aims to explore the applicability of lean principles in a service context and to conceptualize how these principles impact service productivity.

Design/methodology/approach: This paper presents a conceptual analysis of the six most commonly used lean principles in manufacturing and their applicability to a service context for different types of services. Using this analysis, six propositions are developed to examine the influence of lean on service productivity.

Findings: This study suggests promising synergies, as well as important obstacles, for applying lean principles in services. Standardizing services and increasing reliability in service processes through lean principles can increase efficiency. However, the customer's active role in certain services and, simultaneously, high diversity make the application of lean principles increasingly difficult. Also, customer satisfaction must be considered when improving service productivity, otherwise the positive long-term effects of a lean approach in service will be absent.

Practical implications: These findings are useful for organizations aiming to improve their service productivity. Particularly, lean principles are invaluable to increase efficiency and customer satisfaction for services with low diversity and low customer participation. This paper suggests a direction for the proper use of lean principles for different service types, and how efficiency and customer satisfaction are affected through a lean approach. 
Originality/Value: This study contributes to the research on service productivity and continues the discussion on prototypic characteristics of service and manufacturing orientations.

KEYWORDS: Lean principles, service productivity, service process, efficiency, customer satisfaction

PAPER TYPE: Conceptual paper 


\section{Introduction}

During the last decades, various lean approaches have received much attention and have been successful in improving productivity, especially in manufacturing (for example, see Ohno, 1988; Womack, Jones, \& Roos, 1990), but also other industries, perhaps most notably health care (for example, de Souza, 2009; Landsbergis, Cahill, \& Schnall, 1999; Poksinska, 2010). Womack et al. (1990) established the term "lean" in the 1980s, describing its main objective as increasing efficiency through minimizing costly non-value-adding activities while retaining customerperceived value. According to lean, all types of non-value-adding activities are waste, and consequently, must be consistently and thoroughly eliminated (Hines, Holweg, \& Rich, 2004; Womack \& Jones, 2003). For instance, Toyota is considered a prime example of a firm that successfully applies lean.

At the same time, increasing competition in services puts pressure on firms' profit margins, which actualizes the need to examine productivity in this sector (Anderson, Fornell, \& Rust, 1997; Grönroos, 2007; Rust \& Huang, 2012). How to work with productivity issues in services has long been challenging, and scant research exists in this area (Geum, Shin, \& Park, 2011). In addition, services typically vary significantly in how they are produced (the production processes), which makes productivity challenging to manage. Scholars from various disciplines have called for more research on service productivity (Anderson et al., 1997; Filiatrault, Harvey, \& Chebat, 1996; Parasuraman, 2002; Rahikka, Ulkuniemi, \& Pekkarinen, 2011; Rust \& Huang, 2012; Rust, Moorman, \& Dickson, 2002). Exploring the applicability of a lean approach for improving productivity in services can be a valuable contribution to the ongoing debate and promises managerial insights regarding how to coordinate and manage productivity efforts in services.

The aim of this research is two-fold: (1) to explore the applicability of lean in a service context, and (2) to conceptualize how lean principles might impact service productivity. This paper begins with a description of lean principles and service production, and continues with an 
analysis of the application of lean principles to different service types. Six propositions examining the influence of each lean principle on service productivity are identified. Finally, conclusions and managerial implications are presented.

\section{The lean principles}

Traditionally, lean is often interpreted as an opportunity for organizations to improve efficiency and to create a new platform for competitiveness (James-Moore \& Gibbons, 1997). Since its introduction in 1988 (Krafcik, 1988), lean has been one of the most influential philosophies in the manufacturing industries (Shah \& Ward, 2007). Mainly a production philosophy (originating from the Toyota Production System), lean initially focused on improving efficiency in mass production (Womack \& Jones, 2003); however, no common definition exists. Lean is alternately defined as a strategic perspective, a tactical toolbox, a philosophy, and a method (Langstrand, 2012). The concept primarily is seen in production and operation management (Hines et al., 2004), and few studies have investigated the suitability of lean approaches in contexts other than high volume and mass production (James-Moore \& Gibbons, 1997), with some exceptions primarily concentrated to health care services (for example, de Souza, 2009; Landsbergis et al., 1999; Poksinska, 2010).

The meaning of lean has developed throughout the years, with shifts in the focus of interest (Hines et al., 2004). Just-in-time techniques and a cost focus dominated in the 1980s, whereas later changes included total quality management (TQM) in the first half of the 1990s. From 1990 to 2000 , the main focus was on quality costs and delivery. After 2000 , lean production shifted focus to value rather than cost issues, which overall denotes a more strategic rather than tactical approach. The development from tactical to strategic illustrates a shift from a specific to a more generic lean definition, from a low abstraction level focused on tools and methods to a more abstract concept focused on strategy and philosophy. This more abstract, generic, and less context-dependent concept of lean potentially enables its application to other sectors and fields, such as services. 
The lean literature (for example, Pettersen, 2009; Shah \& Ward, 2007; Womack \& Jones, 2003) includes important recurring issues that can be summarized into six lean principles: define value; define value stream; flow; pull; standardization; and perfection (see Table 1). All these principles are derived from a manufacturing context (Pettersen, 2009; Shah \& Ward, 2007; Womack \& Jones, 2003), and the literature on lean in services remains sparse. The lean principles in Table 1 are moderately abstract but do not discuss lean as a philosophy, a culture, or a way of living. Neither are they concrete tools specifying how to implement lean in organizations. Instead, they describe principles that reflect the broad variety of approaches to lean that exist today. Table 1 summarizes the meaning and implications of these principles as described in literature. 
Table 1. The lean principles in literature and their key characteristics and implications.

\begin{tabular}{|c|c|c|c|}
\hline Lean principle & Literature & Meaning & Implications \\
\hline Define value & $\begin{array}{l}\text { Womack and } \\
\text { Jones (2003), } \\
\text { Pettersen (2009), } \\
\text { Shah and Ward } \\
(2007)\end{array}$ & $\begin{array}{l}\text { Value is always created } \\
\text { by the provider, even } \\
\text { though value is defined } \\
\text { by the customer }\end{array}$ & $\begin{array}{l}\text { What is not adding } \\
\text { value - waste - must } \\
\text { be reduced by } \\
\text { minimizing resources } \\
\text { that do not contribute } \\
\text { to customer value }\end{array}$ \\
\hline $\begin{array}{l}\text { Define value } \\
\text { stream }\end{array}$ & $\begin{array}{l}\text { Womack and } \\
\text { Jones (2003), } \\
\text { Pettersen (2009), } \\
\text { Shah and Ward } \\
(2007)\end{array}$ & $\begin{array}{l}\text { Mapping every step } \\
\text { involved in the } \\
\text { production process }\end{array}$ & $\begin{array}{l}\text { Actions are mapped } \\
\text { into different } \\
\text { categories - those that } \\
\text { create value, as } \\
\text { perceived by the } \\
\text { customer, and those } \\
\text { that do not }\end{array}$ \\
\hline Flow & $\begin{array}{l}\text { Womack and } \\
\text { Jones (2003), } \\
\text { Shah and Ward } \\
\text { (2007) }\end{array}$ & $\begin{array}{l}\text { Focuses on the object } \\
\text { (such as a product, a } \\
\text { customer, or } \\
\text { information) running } \\
\text { through the value } \\
\text { stream }\end{array}$ & $\begin{array}{l}\text { Instead of looking at } \\
\text { the resources available } \\
\text { and how to use them } \\
\text { efficiently, flow focuses } \\
\text { on the process and } \\
\text { how to optimize the } \\
\text { flow of elements } \\
\text { through the process }\end{array}$ \\
\hline Pull & $\begin{array}{l}\text { Womack and } \\
\text { Jones (2003), } \\
\text { Pettersen (2011), } \\
\text { Shah and Ward } \\
(2007)\end{array}$ & $\begin{array}{l}\text { Not producing prior to } \\
\text { an order }\end{array}$ & $\begin{array}{l}\text { Capacity becomes a } \\
\text { critical issue }\end{array}$ \\
\hline Standardization & Pettersen (2009) & $\begin{array}{l}\text { Setting standards to } \\
\text { achieve platforms that } \\
\text { enable improvements }\end{array}$ & $\begin{array}{l}\text { The functionality from } \\
\text { different units can be } \\
\text { controlled and } \\
\text { compared with } \\
\text { different measures }\end{array}$ \\
\hline Perfection & $\begin{array}{l}\text { Womack and } \\
\text { Jones (2003), } \\
\text { Pettersen (2009), } \\
\text { Shah and Ward } \\
(2007)\end{array}$ & $\begin{array}{l}\text { The absolute goal of } \\
\text { lean }\end{array}$ & $\begin{array}{l}\text { The outcome of lean if } \\
\text { all other lean } \\
\text { principles are fulfilled }\end{array}$ \\
\hline
\end{tabular}




\section{Service production}

Service productivity can be challenging because it often includes both efficiency and customer satisfaction parameters (Maroto-Sánchez, 2012). Furthermore, different service production processes can vary in degree of customer participation and in demand (Larsson \& Bowen, 1989). Therefore, a distinction between different service production processes is needed to allow a more comprehensive analysis of the applicability of lean to service productivity.

The following section describes service productivity characteristics in more detail and the various service production process types.

\subsection{Service productivity characteristics}

In a manufacturing context, productivity is perceived primarily as an internally oriented and efficiency focused concept (Maroto-Sánchez, 2012; Parasuraman, 2002), often measured as the ratio between produced output and used input from a provider's perspective (Anderson et al., 1997; Parasuraman, 2002; Sink, 1985). In this respect, the quality of the output is assumed to be constant. However, the quality of a service as perceived by the customer cannot be presumed constant when efficiency is increased because customer-perceived quality can shift according to customer preferences (Anderson et al., 1997; Djellal \& Gallouj, 2010). As customers perceive quality differently, customer satisfaction will vary; therefore, efficiency improvements cannot be assumed to improve the firm's economic results because profitability may drop due to lower customer satisfaction (Grönroos \& Ojasalo, 2004; Johnston \& Jones, 2004). At a given point in time, there is typically a service productivity trade-off between customer satisfaction (as a function of service quality) on the one hand, and efficiency on the other (Rust \& Huang, 2012). In other words, a measure of customer satisfaction must be included in service productivity (Parasuraman, 2002). A literature review by Maroto-Sanchez (2012) discussed an emerging view of productivity as a combination of both efficiency and customer satisfaction, thus resonating with a wider definition of productivity appropriate in a service context. 
In contrast to manufacturing, the service customer typically plays a more active role, providing significant input into the production process; therefore, the customer's perspective must be included to understand service productivity. This perspective includes customer inputs such as time, knowledge, and skills (Geum et al., 2011; Grönroos \& Ojasalo, 2004; Johnston \& Jones, 2004; Parasuraman, 2002) as well as the output of customer satisfaction (Parasuraman, 2002).

To summarize, service productivity in this study consists of efficiency and customer satisfaction (Grönroos \& Ojasalo, 2004; Maroto-Sánchez, 2012; Parasuraman, 2002; Rust \& Huang, 2012), efficiency refers to efficient use of provider and customer resources, and customer satisfaction to the extent that customers are satisfied with the outcome of the service.

\subsection{Service production processes}

In services, customers typically play a vital role in providing inputs and ultimately enhancing (or reducing) their own satisfaction (Bitner, Faranda, Hubbert, \& Zeithaml, 1997; Normann, 2000). Therefore, including the customer's participation into the analysis becomes important. Larsson and Bowen's (1989) framework for different types of services, which stems from the extent to which the customer actively participates in service production, offers an interesting way to approach the applicability of lean to service productivity. Two distinct dimensions in their framework are relevant: diversity of demand and customer disposition to participate. First, managing the diversity of demand is a core issue in lean production (Womack \& Jones, 2003). If the demand were homogeneous for services (as often is assumed in a mass production context), lean would be more readily applicable because individual variations in demand would be small. Second, the customer's disposition to participate is highly relevant because the customer's participation (low or high) is a significant differentiator between service- and product-oriented environments. Services emphasize the active role of the customer (Grönroos, 2008; Normann \& Ramírez, 1993), whereas in manufacturing, the customer is more passive (Bowen et al., 1989; Chase, 1981). Combining these dimensions, the Larsson and Bowen framework composes a typology with four different types of service process design, and the level of input uncertainty 
(due to customer participation) constitutes the diagonal (see Table 2). This framework forms a basis for providing knowledge and a deeper understanding of how lean can be understood in service production.

Table 2. Service typology (Larsson \& Bowen, 1989).

\begin{tabular}{|c|c|c|c|}
\hline & & \multicolumn{2}{|c|}{ Customer disposition to participate } \\
\hline & & Low & High \\
\hline \multirow{3}{*}{$\begin{array}{l}\text { Diversity } \\
\text { in } \\
\text { demand }\end{array}$} & Low & $\begin{array}{l}\text { Pooled service design (PSD) } \\
\text { Allows for standardization routines } \\
\text { and economies of scale. Examples of } \\
\text { PSD include banking and insurance } \\
\text { services. }\end{array}$ & $\begin{array}{l}\text { The customers are given a high } \\
\text { workload. Examples of SSSD include } \\
\text { online services and car rentals. }\end{array}$ \\
\hline & & $\begin{array}{l}\text { Sequential customized service design } \\
\text { (SCSD) }\end{array}$ & Reciprocal service design (RSD) \\
\hline & High & $\begin{array}{l}\text { Offers customers a convenient } \\
\text { solution. Therefore, the workload } \\
\text { remains with the provider's } \\
\text { employees. Examples of SCSD } \\
\text { include car repair and craftwork. }\end{array}$ & $\begin{array}{l}\text { Requires interplay between service } \\
\text { providers and customers during the } \\
\text { service production. Examples of } \\
\text { RSD include psychotherapy and } \\
\text { higher education. }\end{array}$ \\
\hline
\end{tabular}

\section{Discussion - improving service productivity with a lean approach}

The following section discusses the applicability of the six lean principles to different types of service processes according to Larsson and Bowen's (1989) service framework (see Table 2). The findings from this discussion are briefly summarized in Table 3. 
Table 3. Lean principles in services.

\begin{tabular}{|c|c|c|c|c|}
\hline Lean principle & $\begin{array}{l}\text { Pooled service } \\
\text { design }\end{array}$ & \begin{tabular}{|l|} 
Sequential \\
standardized \\
service design
\end{tabular} & \begin{tabular}{|l} 
Sequential \\
customized \\
service design
\end{tabular} & \begin{tabular}{|l|} 
Reciprocal \\
service design
\end{tabular} \\
\hline Define value & $\mathrm{O}$ & $\mathrm{O}$ & $\mathrm{O}$ & $\mathrm{O}$ \\
\hline $\begin{array}{l}\text { Define value } \\
\text { stream }\end{array}$ & $\mathrm{O}$ & $\mathrm{O}$ & $\mathrm{O}$ & $\mathrm{O}$ \\
\hline Flow & $\mathrm{O}$ & $\bigcirc$ & $\bigcirc$ & $\bigcirc$ \\
\hline Pull & $\mathrm{O}$ & $\mathrm{O}$ & $\mathrm{O}$ & $\mathrm{O}$ \\
\hline Standardization & $\mathrm{O}$ & $\mathrm{O}$ & $\bigcirc$ & $\bigcirc$ \\
\hline Perfection & $\mathrm{O}$ & $\mathrm{O}$ & $\mathrm{O}$ & $\mathrm{O}$ \\
\hline
\end{tabular}

Increases both efficiency and customer satisfaction

$O$ Increases efficiency at the expense of customer satisfaction

Table 3 also illustrates how different lean principles influence service productivity, either by improving efficiency (implicitly at the expense of customer satisfaction) or improving both efficiency and customer satisfaction. Theoretically, customer satisfaction could increase at the expense of efficiency; however, this was not the case in this research.

Based on this analysis, propositions regarding the influence of each principle on service productivity for different service types are developed.

\section{LP1 - Define value}

From a lean perspective, the provider creates value, although the customer ultimately defines it; from a service perspective, however, value derives from each customer's use context as customers create value individually or co-create value in their processes together with the 
provider (Grönroos \& Voima, 2013). The value creation in service emphasizes the active role of the customer and value-in-use as the overarching value concept (Kowalkowski, 2011). Acceptance for the notion that value is created in the customer sphere (as value-in-use) is well established in service literature (Grönroos \& Voima, 2013). Hence, from a service point of view, this principle implies that the provider must have a pronounced ability to understand what creates customer-defined value.

By understanding customer value creation and reducing non-value-adding activities, LP1 could be beneficial in increasing both efficiency and customer satisfaction. This approach requires a thorough understanding of the firm and the customer processes to determine whether an activity is value-adding. For example, in standardized sequential services, customers are typically price sensitive since they forgo customization and contribute with their own labor (Larsson \& Bowen, 1989). With this awareness, the provider can adapt service production to reduce costs and standardize customer interfaces. For reciprocal services, on the other hand, other aspects are important for creating customer value. Here, the customer values expertise and solutions to specific - often customer unique - problems. Therefore, these services can be designed to better fit the customer's need, thereby increasing both efficiency and customer satisfaction.

The above discussion leads to proposition 1:

The provider should strive to understand value as defined by the customer. To define value and to eliminate waste imply a focus on reducing non-value-adding activities and resources in the provider and customer processes, and thus increase both efficiency and customer satisfaction for all service types.

\section{LP2 - Define value stream}

This principle, which is a generic process that maps the activities and actions necessary for producing a service, can be applied to all service types and is not restricted to the provider's 
processes. Rather, the actions of other actors must be considered, specifically, the customers' actions must be defined (Eichentopf, Kleinaltenkamp, \& van Stiphout, 2011; Grönroos \& Ojasalo, 2004). The traditional lean principle does not consider customers' actions, and therefore, the lean principle must be extended to better fit a service context. In service, value is primarily created in customer processes (Grönroos \& Voima, 2013). A thorough mapping will reveal redundant activities, as well as those that can be shared across different services. Methods for this mapping that clearly involve customers include service blueprinting (Bitner, Ostrom, \& Morgan, 2008) and customer scripts (Eichentopf et al., 2011). A customer script can be used in reciprocal services, such as higher education in which the script reveals what the student must contribute with (prior knowledge, time, and so on), what the university must provide (such as teachers, computers, lecture halls), and where and how interactions occur.

Mapping value streams with a customer script can be an important tool to reveal wasteful activities that do not contribute to customer value creation. If this mapping is done for both provider and customer activities, it can be used to increase both efficiency and customer satisfaction. Efficiency may be increased because the production process can be improved, and customer satisfaction may improve because value stream mapping can reveal what resources and efforts the customer contributes and what affects customer satisfaction. Thus, defining value stream will contribute to more accurate use of resources, as well as better coordination among customer, provider, and other actors in customer value creation.

The above discussion leads to proposition 2:

Mapping value streams potentially will increase both efficiency and customer satisfaction in all service types.

\section{LP3 - Flow}

Although some recent lean literature emphasizes the customer to some extent (Pettersen, 2009), the customer is still perceived as a flow element within the provider's own service processes. 
The question is not how to support the customers' processes, but rather how to address the customer, or the product, as a so-called flow-brick in the provider's processes. Therefore, the applicability of flow in service seems limited. However, for services in which diversity of demand is low and customers' disposition to participate is low, the flow principle can be beneficial. Using the flow principle in this situation has the potential to improve efficiency for the service provider without negatively affecting customer satisfaction. It may even affect customer satisfaction positively. For example, an airline can consider the passenger as a flow element around which processes are arranged to contribute to customer satisfaction. For example, flow speed through the production process can be increased as wait time at the gate and boarding time are reduced. However, this principle primarily prevails when the customer is rather passive, that is, when a low level of customer participation exists (Bitner et al., 1997). Applying the flow principle to health care, Modig and Åhlström (2012) considered the patient as a flow brick. When the customer's knowledge is low and the participation rate is low, the flow principle works relatively well; however, when the customer participates to a greater extent with his own efforts and resources, application of the flow principle is more difficult because the customer helps create the service instead of being a flow-brick in the provider's internal process. Flow can potentially improve both efficiency and customer satisfaction; however, for service types with high variety and high customer participation, there is a potential risk that customer satisfaction will decrease with application of a standardized system that does not fit every customer. In addition, difficulties in achieving flow are inherent with an active customer (or patient, as in the previous example), and more customer involvement also increases input uncertainty (Larsson \& Bowen, 1989). Furthermore, Johnston and Jones (2004) argued that a faster flow can increase efficiency but may reduce customer satisfaction because actively pushing the customer/patient through the flow may negatively affect the customer's emotional experience.

The above discussion leads to proposition 3: 
Flow can be useful to increase efficiency and customer satisfaction for pooled services. For services with high diversity in demand and high customer participation, efficiency improvements will be at the expense of customer satisfaction.

\section{LP4 - Pull}

The pull principle means that the services are not produced before the order is placed. Most services respond to customer needs because they generally are not produced prior to an existing customer request. Therefore, the pull principle is an inherent characteristic of services, although services also may be produced in anticipation of demand. For example, ICT-based services can be produced and "stored" before use (Lovelock and Gummesson, 2004). Nevertheless, the pull principle can be applicable for services regardless of whether diversity is low or high or whether the customer's disposition to participate is low or high.

One example is a Service Level Agreement (SLA). A customer signs up for a service contract (SLA) and the firm's response is to offer a set of activities and deeds. The service cannot be stored and produced before demand occurs, but nevertheless, the firm constantly must forecast the number of customers (and SLAs) in order to have the right competencies and quantities of resources available (equipment, personnel, and so on).

The pull principle can have positive effects on both efficiency and customer satisfaction as long as the provider's capacity is adequate (and available). If capacity is low and demand is high, customer satisfaction may be negatively affected because the customer may not receive the service in time. As services typically are difficult to store, managing capacity (and also demand) becomes a challenge for many service providers. If customers never have to wait for services, their satisfaction will be positively affected; however, efficiency will be negatively affected because slack resources must be increased.

The above discussion leads to proposition 4: 
The pull principle is typically embedded in the characteristics of most services. As such, pull serves as a mechanism to match supply and demand, improving customer satisfaction and efficiency for all service types, if capacity can be managed properly.

\section{LP5 - Standardization}

Although standardization and productivity of services is an emerging topic in service research (Calabrese, 2012; Sundbo, 2002), standardization as a lean principle is not easy to apply in services. Application is especially difficult for services with high diversity (for example, psychotherapy, higher education, and car repair) because customization is an inherent part of those services and their processes. However, for services with low diversity in demand, such as more repetitive and high volume services, standardization may be beneficial. For example, banking, insurance, car rental, and laundry services can be standardized rather easily without negatively affecting customer satisfaction because these services' customers forgo customization in preference for low price and reliability. On the other hand, as mentioned, services with high diversity (such as psychotherapy) cannot be standardized because every patient needs individual treatment; instead, these customers value a greater degree of customization.

Accordingly, standardization can potentially increase efficiency as the provider's input can be optimized in terms of technology, production processes, and time. Such standardization should not negatively affect customer satisfaction for services with low diversity in demand. However, for a range of services, especially services with high diversity in demand, this lean principle misses the target because customer satisfaction will decrease.

The above discussion leads to proposition 5:

Standardization can serve as a tool to increase efficiency as well as customer satisfaction for service processes with low diversity in demand. For other services, standardization increases efficiency at the expense of customer satisfaction. 


\section{LP6 - Perfection}

The lean principle of perfection is somewhat difficult to apply because perfection can be seen as the result of successfully applying the previous principles. If the other principles are fulfilled, then activities that waste time and resources are eliminated and perfection is achieved. However, treating perfection as the goal of a service business means it is applicable to all types of services; perfection occurs when the customer is satisfied with the service and when the right amount of resources have been used to produce the service. From this perspective, perfection is achieving service excellence with a maximum of customer satisfaction while simultaneously achieving high efficiency. As not all lean principles are applicable for all service types, the definition of perfection will differ among service types.

Perfection can serve as a target for service organizations, basically being interpreted as the optimal trade-off between efficiency and customer satisfaction. How such optimum should be achieved ultimately depends on the type of service in focus and the specific use context.

The above discussion leads to proposition 6:

Even if perfection, from a lean perspective, is not always possible to achieve, it can be used to reflect the search for improvements in both efficiency and customer satisfaction for all service types. But perfection must be interpreted differently for various types of services because not all lean principles are applicable for all service types.

\section{Conclusions and theoretical implications}

Traditionally, lean has been mainly applied to manufacturing; however, this research proposes that applying lean principles to address productivity in services can be beneficial. An appropriate lean approach as discussed in this study can improve efficiency as well as customer satisfaction. According to previous research, an increase in efficiency in services typically is connected with lower customer satisfaction (Anderson et al., 1997). Nevertheless, significant potential exists for improving service productivity by applying various lean principles. The 
research suggests that such an approach can become an important part of new service development, as well as service deployment.

Importantly, the original meaning of the lean concept strongly emphasizes internal flow efficiency, which risks negatively affecting customer satisfaction. Consequently, all lean principles are not applicable to all services and their associated service production processes. According to Larsson and Bowen's (1989) framework, a reciprocal or sequential customized service design exhibits a greater risk of decreasing customer satisfaction when applying a lean approach. Therefore, the benefit of using lean principles in these service designs is relatively limited compared with the other two types of service design. A lean approach has the highest potential when the service provider produces the service primarily in isolation from the customer, or when the customer produces the service primarily away from the service provider (pooled and sequential standardized service design). In addition, lean principles work best when the volatility of demand is low (Lee et al., 2008). In particular, most lean principles are particularly applicable to a pooled service design with low diversity of demand and a low degree of customer participation. This finding is not surprising since this type of service has the most characteristics in common with traditional manufacturing activities.

In line with an emphasis on internal flow, this study points out the importance of extending the lean concept to include customer-oriented elements and elements from other actors in the value constellation to realize the full potential of lean principles in services. For certain lean principles, such as defining value and flow, inclusion of external elements becomes pivotal because it may increase the value creation potential in non-service contexts where a greater understanding of customer elements and processes can lead to new opportunities.

While the Larsson and Bowen (1989) framework is static in the sense that a certain service has a certain process design, the reality is dynamic. Service process designs may change because of technological advancements intended to improve productivity, such as remote diagnostics, automated phone systems, and Internet banking. New technology enables not only more self- 
service activities, but also more activities performed without direct customer contact.

Consequently, many services no longer require the same degree of reciprocity and more services potentially may become sequential or pooled (Kowalkowski \& Brehmer, 2008). This means that the applicability of lean principles for a particular type of service may change over time, as advances of various technologies can enable new service process designs. In addition, it may be possible to redesign services and their associated production processes to facilitate productivity improvements through the application of lean.

To date, research on lean principles in service generally has been limited to the health care sector. This study offers a nonsectorial conceptualization of the application of lean principles in service; that is, rather than focusing on particular service industries, this study offers a general framework that can be applicable regardless of industry. Another contribution is the development of six propositions (one per lean principle) for how lean principles impact service productivity.

Because lean principles originated in manufacturing, which is a particular type of production setting (the closed manufacturing system), the impact of these principles on service productivity depends on how much the service design resembles the archetypal manufacturing setting. Such a differential use of lean principles contributes to both lean and service productivity research. The ultimate goal of lean (perfection) must be interpreted differently for various types of services. Particularly for more interactive services, the application of some lean principles might reduce customer satisfaction, thus deviating from the principle of perfection and reducing overall service productivity.

Methodologically, lean principles are rather abstract and difficult to implement. As in manufacturing, tools and methods for each principle are needed for implementation in services, but it might not be enough to differentiate the use of tools and methods according to service type. For example, in lean principles regard value as being created by the provider, an idea that does not resonate with a service logic (cf. Grönroos, 2007). This study aligns with Radnor and 
Osborne's (2013) claim that implementation of lean in services has been defective (the focus has been on the technical tools of implementation), and argues that lean must resonate with a service logic. Therefore, in addition to specific tools and methods, successful implementation and improved service productivity requires alignment between the tools and methods on one hand and the firm's business logic (in this case, service logic) on the other; therefore, lean as a set of practices may need to be adapted to fit a service logic.

To conclude, differentiating the use of lean principles, based on service types, offers a greater potential for improvements in efficiency that will not negatively affect customer satisfaction. Therefore, a lean approach to service productivity is not necessarily an oxymoron; its applicability depends on the type of services offered.

\section{Managerial implications}

This research derives a number of managerial insights when considering the application of lean in services. In lean, the customer is primarily a passive actor, and quality in production is a concern only of functionality because the provider produces value (the product) in isolation from the customer. In contrast, service literature emphasizes the active customer and reciprocity. Therefore, in services, it is critical to understand and analyze the resources, such as the time and effort the customer invests, as one part of productivity. This becomes especially important for service types were the customer is active (sequential, standardized, and reciprocal service design).

Furthermore, managers must take into account the diversity of demand. If the service has a high diversity of demand, then increasing productivity by focusing solely on efficiency (such as through downsizing) might not be appropriate. This approach probably will lead to lower customer satisfaction, and in the longer term, lower profitability. Instead, an emphasis on customer satisfaction potentially may be a more relevant approach in a service context. 
The framework presented in Table 3 offers a first attempt to apply lean principles in a service context. For managers, the links between lean principles and service processes can serve as a starting point for development of lean tools and methods suitable to the specific services they offer. The six propositions, corresponding to each of the lean principles, summarize the findings and offer initial guidance for how managers can approach the lean concept in services.

By redesigning services, and the associated service processes, managers can increase the applicability of lean. However, most important, managers must realize that what is internally efficient for the organization is not always a sufficient strategy for increasing service productivity because customer satisfaction must be considered. Prioritizing internal efficiency typically is connected to a firm-centric viewpoint, rather than a customer-centric one in which the customer's perception of what is effective is most important.

To apply lean principles in a service context and to successfully improve efficiency, managers must thoroughly understand the customers' operational processes, and also understand how different service types require unique adaptations of the lean principles for improving productivity. Rather than focusing only on internal improvements, opportunities for service productivity improvements - and value creation - also may be found in identifying customer process improvements and even "teaching" customers certain behaviors (Payne, Storbacka \& Frow, 2008). This study suggests that lean can be a valuable tool for managers to balance efficiency and customer satisfaction, hence offering opportunities to better understand and improve service productivity.

\section{Future research}

An interesting avenue for future research would be to investigate how the application of lean principles affects the customer's perception of the service process. This relationship is typically overlooked as firms strive to improve productivity through lean. Yet, the aspects that the customer appreciates and sees as drawbacks to the lean approach in service processes must be 
taken into account. This research direction also could contribute more empirical insights, which should be a high priority in any future studies investigating the use of lean in services.

From a managerial perspective, studies that gauge the customer's perspective will be beneficial because they may serve as a strategic tool to indicate where, and for which service processes, lean principles can be applied. Such information could help managers determine whether efficiency improvements will lead to increased revenues, as such a benefit will not arise if customer satisfaction is negatively affected to any great extent. This future direction also could provide additional theoretical contributions since empirical research concerning the customer's perspective is sparse.

\section{References}

Anderson, E. W., Fornell, C., \& Rust, R. T. (1997). Customer satisfaction, productivity and profitability: Differences between goods and services. Marketing Science, 16(2): 129145.

Bitner, M. J., Faranda, W. T., Hubbert, A. R., \& Zeithaml, V. A. (1997). Customer contributions and roles in service delivery. International Journal of Service Industry Management, 8(3): 193-205.

Bowen, D. E., Siehl, C., \& Schneider, B. (1989). A framework for analyzing customer service orientations in manufacturing. Academy of Management Review, 14(1): 75-95.

Bitner, M. J., Ostrom, A. L., \& Morgan, F. N. (2008). Service blueprinting: A practical technique for service innovation. California Management Review, 50(3): 66-94.

Calabrese, A. (2012). Service productivity and service quality: A necessary trade-off? International Journal of Production Economics, 135(2): 800-812.

Chase, R. B. 1981. The customer contact approach to services: Theoretical bases and practical experience. Operations Research, 29(4): 698-706.

De Souza, B. L. (2009). Trends and approaches in lean healthcare. Leadership in Health Services, 22(2): 121-139.

Djellal, F., \& Gallouj, F. (2010). Beyond productivity strategies in services. Journal of Innovation Economics, 5(1): 89-104.

Eichentopf, T., Kleinaltenkamp, M., \& van Stiphout, J. (2011). Modelling customer process activities in interactive value creation. Journal of Service Management, 22(5): 650-663.

Filiatrault, P., Harvey, J., \& Chebat, J.-C. (1996). Service quality and service productivity management practices. Industrial Marketing Management, 25(3): 243-255.

Geum, Y., Shin, J., \& Park, Y. (2011). FMEA-based portfolio approach to service productivity improvement. Service Industries Journal, 31(11): 1825-1847.

Grönroos, C. (2007). Service Management and Marketing-Customer Management in Service Competition (3rd ed.). Chichester, UK: John Wiley \& Sons Ltd.

Grönroos, C. (2008). Service-dominant logic revisited: Who creates value? And who co-creates? 
European Business Review, 20(4): 298-314.

Grönroos, C., \& Ojasalo, K. (2004). Service productivity: Towards a conceptualization of the transformation of inputs into economic results in services. Journal of Business Research, 57(4): 414-423.

Grönroos, C., \& Voima, P. (2013). Critical service logic: making sense of value creation and cocreation. Journal of the Academy of Marketing Science. 41(2): 133-150.

Hines, P., Holweg, M., \& Rich, N. (2004). Learning to evolve: A review of contemporary lean thinking. International Journal of Operations \& Production Management, 24(10): 9941011.

James-Moore, S. M., \& Gibbons, A. (1997). Is lean manufacture universally relevant? An investigative methodology. International Journal of Operations \& Production Management, 17(9): 899-911.

Johnston, R., \& Jones, P. (2004). Service productivity towards understanding the relationship between operational and customer productivity. International Journal of Productivity and Performance Management, 53(3): 201-213.

Kowalkowski, C. (2011). Dynamics of value propositions: insights from service-dominant logic, European Journal of Marketing, 45(1/2): 277-294.

Kowalkowski, C. \& Brehmer, P.O. (2008). Technology as a driver for changing customer-provider interfaces: Evidence from industrial service production, Management Research News, 31(10): 746-757.

Krafcik, J. F. (1988). Triumph of the lean production system. Sloan Management Review, 30(1): $41-52$.

Landsbergis, P. A., Cahill, J., \& Schnall, P. (1999). The impact of lean production and related new systems of work organization on worker health. Journal of Occupational Health Psychology, 4(2): 108-130.

Langstrand, J. (2012). Exploring organizational translation: A case study of changes toward lean production. Published doctoral dissertation. Linköping University, Linköping.

Larsson, R., \& Bowen, D. E. (1989). Organization and customer: Managing design and coordination of services. Academy of Management Review, 14(2): 213-233.

Lee, S. M., Olson, D. L., Lee, S.-H., Hwang, T., \& Shin, M. S. (2008). Entrepreneurial applications of the lean approach to service industries, The Service Industries Journal, 28(7): 973-987.

Lovelock, C., \& Gummesson, E. (2004). Whither services marketing? In search of a new paradigm and fresh perspectives. Journal of Service Research, 7(1): 20-41.

Maroto-Sánchez, A. (2012). Productivity in the services sector: Conventional and current explanations. The Service Industries Journal, 32(5): 719-746.

Modig, N., \& Åhlström, P. (2011). Vad är lean? Stockholm: Stockholm School of Economics Institute for Research.

Normann, R. (2000). Service Management (3rd ed.). Chichester, UK: John Wiley \& Sons, Ltd.

Normann, R., \& Ramírez, R. (1993). From value chain to value constellation: Designing interactive strategy. Harvard Business Review, 71(4): 65-77.

Ohno, T. (1988). The Toyota Production System: Beyond Large-Scale Production. New York: Productivity Press.

Parasuraman, A. (2002). Service quality and productivity: A synergistic perspective. Managing Service Quality, 12(1): 6-9. 
Payne, A., Storbacka, K., \& Frow, P. (2008). Managing the co-creation of value. Journal of the Academy of Marketing Science. 36(1): 83-96.

Pettersen, J. (2009). Defining lean production: Some conceptual and practical issues. The TQM Journal, 21(2): 127-142.

Poksinska, B. (2010). The current state of lean implementation in health care: Literature review. Quality Management in Health Care, 19(4): 319-329.

Radnor, Z. \& Osborne, S. P. (2013). Lean: A failed theory for public services? Public Management Review, 15(2): 265-287.

Rahikka, E., Ulkuniemi, P., \& Pekkarinen, S. (2011). Developing the value perception of the business customer through service modularity. Journal of Business \& Industrial Marketing, 26(5): 357-367.

Rust, R. T., \& Huang, M.-H. (2012). Optimizing service productivity. Journal of Marketing, 76(2): $47-66$.

Rust, R. T., Moorman, C., \& Dickson, P. R. (2002). Getting return on quality: Revenue expansion, cost reduction, or both? Journal of Marketing, 66(4): 7-24.

Shah, R., \& Ward, P. T. (2007). Defining and developing measures of lean production. Journal of Operations Management, 25(4): 785-805.

Sink, D.S. (1985). Productivity management - Planning, measurement and evaluation, control and improvement. Chichester: Wiley.

Sundbo, J. (2002). The service economy: Standardisation or customisation? Service Industries Journal, 22(4): 93-116.

Womack, J. P., \& Jones, D. T. (2003). Lean Thinking: Banish Waste and Create Wealth in Your Corporation. Sydney: Simon \& Schuster.

Womack, J. P., Jones, D. T., \& Roos, D. (1990). The Machine That Changed the World: The Story of Lean Production. New York: Rawson Associates. 